\title{
RESPONS FISIOLOGI MATA IKAN SELAR (Selaroides leptolepis) DAN KEMBUNG (Rastreliger brachysoma) TERHADAP WARNA CAHAYA LAMPU
}

\section{PHYSIOLOGICAL RESPONSE OF THE EYE YELLOW-STRIPED SCAD (Selaroides leptolepis) AND SHORT MACKEREL (Rastreliger brachysoma) TO THE COLOR OF LIGHT}

\author{
Fuad $^{1 *}$, Mulyono S Baskoro ${ }^{2}$, Mochammad Riyanto ${ }^{2}$, \& Wazir Mawardi² \\ ${ }^{1}$ Program Studi Pemanfaatan Sumberdaya Perikanan, FPIK-UB, Malang, 65145 \\ ${ }^{2}$ Departemen Pemanfaatan Sumberdaya Perikanan, FPIK-IPB, Bogor, 16680 \\ "E-mail: mrfuad2004@yahoo.com
}

\begin{abstract}
The physiological response of the eye yellow-striped scad (Selaroides leptolepis) and short mackerel (Rastreliger brachysoma) are different for each color of light. The physiological response of the eye fish can be used as an indicator to determine the level of attraction of fish to specific colors of light. This study aims to identify the level of attraction of yellow-striped scad and short mackerel to light white, yellow, green and blue. The research was performed by experiment on lift net. Ten individual yellow-striped scad and short mackerel caged with a net. The fish lighted for 30 minutes. Then the fish was taken the eye, and histological analysis carried out. Data analysis used in this research were regression of fish size, con cells index and speed of con cells movement. The results showed that yellow-striped scad was very responsive to green and blue light. The short mackerel was more responsive to blue light. The average con cells index of yellow-striped scad for blue and green light were $77.3 \pm 7.4 \%$ and $70.7 \pm 6.8 \%$, respectively. On the other hand, the average con cells index of short mackerel for blue light was $79.9 \pm 2.0 \%$. The average speed of con cells movement of yellow-striped scad for blue light was $0.0180 \pm 0.0028 \mu \mathrm{m} / \mathrm{sec}$, and the short mackerel for green light was $0.0157 \pm 0.0018 \mu \mathrm{m} / \mathrm{sec}$. Based on the result of study can be conclouded that the yellow-striped scad was very attracted in green and blue light, while short mackerel was very attracted to blue light.
\end{abstract}

Keywords: cone cell, light, light emiting diode, physiological response

\begin{abstract}
ABSTRAK
Respons fisiologi mata ikan selar (Selaroides leptolepis) dan ikan kembung (Rastroliger brachysoma) berbeda untuk setiap warna cahaya. Respons fisiologi mata ikan bisa dijadikan indikator dalam menentukan tingkat ketertarikan ikan terhadap warna cahaya tertentu. Penelitian ini bertujuan untuk mengidentifikasi tingkat ketertarikan ikan selar dan ikan kembung terhadap cahaya warna putih, kuning, hijau dan biru. Metode penelitian menggunakan metode percobaan yang dilakukan di bagan tancap. Sepuluh ekor ikan selar dan ikan kembung yang dibatasi dengan jaring diberi cahaya selama 30 menit. Sampel ikan yang telah diberi perlakuan cahaya diambil matanya dan dilakukan analisis histologi. Analisis data yang digunakan dalam penelitian ini adalah analisis regresi ukuran ikan, indeks sel kon dan kecepatan pergerakan sel kon. Hasil penelitian menunjukkan bahwa ikan selar sangat tertarik terhadap cahaya LED warna hijau dan biru, sedangkan ikan kembung tertarik terhadap cahaya warna biru. Rata-rata indeks sel kon ikan selar pada cahaya warna biru dan hijau adalah 77,3 $\pm 7,4 \%$ dan $70,7 \pm 6,8 \%$, sedangkan rata-rata indeks sel kon ikan kembung yang diberi cahaya warna biru adalah $79,9 \pm 2,0 \%$. Kecepatan rata-rata pergerakan sel kon ikan selar yang diberi cahaya biru mencapai $0,0180 \pm 0,0028 \mu \mathrm{m} /$ det, sedangkan ikan kembung dengan cahaya hijau adalah $0,0157 \pm 0,0018 \mu \mathrm{m} / \mathrm{det}$. Berdasarkan hasil penelitian dapat disimpulkan bahwa ikan selar sangat tertarik terhadap cahaya warna hijau dan biru, sedangkan ikan kembung sangat tertarik terhadap cahaya warna biru.
\end{abstract}

Kata Kunci: cahaya, light emiting diode, respons fisiologi, sel kon 


\section{PENDAHULUAN}

Warna dan intensitas cahaya sangat mempengaruhi keberhasilan lampu dalam memikat ikan (Guntur et al., 2015; Choi et al., 2009). Setiap jenis ikan memiliki ketertarikan yang berbeda terhadap warna cahaya (Nguyen \& Winger, 2019). Ikan pelagis kecil lebih tertarik terhadap warna cahaya hijau, biru dan kuning (Nguyen \& Winger, 2019; Susanto et al., 2017; Matsui et al., 2016; Guntur et al., 2015; Matsushita et al., 2012). Ikan belanak lebih tertarik terhadap cahaya warna putih (Marchesan et al., 2005). Ikan selar dan ikan kembung sangat menyukai cahaya warna hijau (Fuad et al., 2019; Susanto et al., 2017). Ketertarikan ikan pelagis kecil terhadap cahaya bisa dilihat dari tingkah laku ikan dan fisiologi ikan. Ikan yang tertarik terhadap cahaya akan memberikan respons yang cepat untuk datang ke sekitar cahaya (Kurnia et al., 2015). Kecepatan ikan datang ke sekitar cahaya dan kecepatan ikan membentuk gerombolan merupakan indikator yang sering digunakan untuk menilai tingkat ketertarikan ikan terhadap cahaya. Susanto et al. (2017) mengatakan bahwa ikan selar paling cepat datang dan membentuk gerombolan saat diberi cahaya warna hijau. Cahaya warna kuning dan putih memiliki sebaran cahaya cukup baik dan disukai oleh ikan (Yeh et al., 2015; Shen et al., 2013). Informasi tentang tingkat ketertarikan ikan pelagis kecil terhadap cahaya sangat penting untuk menentukan jenis ikan target penangkapan. Informasi tingkat ketertarikan ikan pelagis kecil terhadap cahaya perlu dikaji lebih jauh pada aspek fisiologi ikan. Informasi ini masih sangat jarang dan belum banyak dilakukan oleh peneliti perikanan tangkap. Kajian respons fisiologi ikan pelagis kecil diharapkan dapat memberikan informasi yang lebih detail tentang ketertarikan ikan terhadap cahaya.

Respons fisiologi mata ikan terhadap cahaya bisa dilihat dari dua indikator yaitu respons pupil dan respons retina mata ikan
(Matsui et al., 2016). Retina mata ikan yang terpapar cahaya akan mengalami pergerakan sel kon dari pigment epithelium membrane (PEM) ke outer limiting membrane (OLM) (Kelber, 2016). Respons retina mata ikan terhadap cahaya bertujuan untuk mengontrol intensitas dan warna cahaya yang masuk (Siebeck et al., 2008). Respons retina mata ikan berbeda untuk setiap warna dan intensitas cahaya. Perbedaan respons retina ini bisa dijadikan indikator untuk mengukur tingkat ketertarikan ikan terhadap cahaya. Penelitian respons ikan terhadap cahaya pernah dilakukan oleh beberapa peneliti sebelumnya. Matsushita et al. (2012) menggunakan warna cahaya biru untuk menangkap ikan cumi-cumi. Guntur et al. (2015) merekomendasikan penggunaan cahaya warna kuning untuk menangkap ikan pelagis kecil. Susanto et al. (2017) mengatakan ikan selar sangat tertarik terhadap warna cahaya hijau. Shen et al. (2013) mengatakan cahaya warna putih memiliki sebaran cahaya yang paling baik di perairan. Penelitian ini menggunakan warna cahaya yang disarankan oleh peneliti sebelumnya yaitu warna biru, hijau, kuning dan putih. Keempat warna lampu ini juga banyak tersedia di toko-toko lampu hemat energi.

Spesies ikan yang digunakan pada penelitian ini adalah ikan selar (S. leptolepis) dan ikan kembung ( $R$. brachysoma). Kedua jenis ikan ini banyak terdapat di perairan pantai dan lebih mudah ditangkap. Ikan selar dan ikan kembung merupakan ikan yang memiliki sifat fototaksis positif terhadap cahaya. Ikan selar dan ikan kembung memiliki jumlah sel kon yang lebih dominan dari pada sel rod pada retinanya. Tujuan penelitian ini adalah mengidentifikasi tingkat ketertarikan ikan selar dan ikan kembung terhadap cahaya, mengetahui hubungan ukuran ikan dengan kecepatan pergerakan sel kon, menganalisis indeks sel kon, panjang lintasan sel kon dan kecepatan pergerakan sel kon. Informasi ini sangat penting untuk mengetahui warna cahaya yang paling 
disukai oleh ikan selar dan ikan kembung. Hasil penelitian juga sangat bermanfaat untuk menentukan waktu pencahayaan saat penangkapan ikan agar tidak melebihi titik jenuh.

\section{METODE PENELITIAN}

\subsection{Waktu dan Lokasi}

Penelitian dilakukan selama dua bulan, 2 Juni sampai 30 Juli 2018 di dua lokasi yaitu penelitian lapangan dilakukan di Perairan Pasuruan Jawa Timur dan analisis sampel mata ikan dilakukan di laboratorium kesehatan ikan FPIK IPB. Penelitian lapangan dilakukan pada malam hari di bagan tancap yang berukuran $12 \times 12 \mathrm{~m}^{2}$. Sampel ikan selar dan ikan kembung diperoleh dari hasil tangkapan bagan tancap. Sampel ikan selar dan ikan kembung ditampung terlebih dahulu sebelum diberi perlakuan cahaya. Terdapat 40 sampel ikan penelitian, 20 ekor ikan selar dan 20 ekor ikan kembung. Ukuran ikan selar yang digunakan dalam penelitian memiliki panjang 9-13,5 cm dengan berat 14-31,1 g. Sedangkan ukuran ikan kembung memiliki panjang $12-16,4 \mathrm{~cm}$ dengan berat $20-44 \mathrm{~g}$.

\subsection{Pengambilan Data}

Sampel ikan selar dan ikan kembung yang telah tertangkap sebelumnya dibiarkan selama 20 menit dalam kondisi gelap. Setelah ikan sudah tenang dan beradaptasi dengan lingkungan, ikan dipindahkan pada jaring perlakuan yang telah disiapkan sebelumnya. Terdapat dua jaring perlakuan dengan panjang dan lebar masing-masing $9 \mathrm{~m}$ dan kedalaman 3,5 m. Perlakuan warna cahaya terhadap sampel ikan dilakukan secara bertahap karena hanya ada dua jaring pelakuan. Tahap pertama pemberian perlakuan warna cahaya biru dan hijau (Figure $1 c$ dan $1 d$ ), tahap kedua pemberian perlakuan warna cahaya kuning dan putih (Figure $1 a$ dan $1 b$ ). Pemberian perlakuan warna cahaya dilakukan selama 30 menit (Pankhurst \& Herbert, 2013). Setelah diberi perlakuan, sampel ikan diangkat dengan cepat, dimatikan dan dilakukan identifikasi. Tahapan identifikasi sampel ikan mengacu pada Efendie (1979). Ikan yang telah diidentifikasi diambil matanya. Sampel mata ikan dimasukkan ke larutan buffered neutral formalin (BNF). Warna cahaya lampu LED yang digunakan pada penelitian ini adalah cahaya putih $(1080 \mathrm{~lm} / \mathrm{m})$, kuning (220 $\mathrm{lm} / \mathrm{m})$, hijau $(550 \mathrm{~lm} / \mathrm{m})$ dan biru $(170 \mathrm{~lm} / \mathrm{m})$. Lampu LED putih memancarkan cahaya antara 2E-006 watt $/ \mathrm{cm}^{2}-8 \mathrm{E}-008 \mathrm{watt} / \mathrm{cm}^{2}$. Lampu LED biru dan hijau memancarkan cahaya antara 2E-006 watt $/ \mathrm{cm}^{2}$-2E-008 watt $/ \mathrm{cm}^{2}$. Lampu LED kuning memancarkan cahaya antara 2E-006 watt/cm ${ }^{2}-4 \mathrm{E}-008$ watt $/ \mathrm{cm}^{2}$.

Sampel mata ikan yang telah diberi perlakuan warna cahaya dibawa ke laboratorium untuk dilakukan analisis histologi. Tahapan proses analisis histologi retina mata ikan mengacu pada Riyanto et al. (2011). Sampel mata ikan yang telah direndam dalam larutan buffered neutral formalin (BNF) selama 24-36 jam. Selanjutnya sampel mata ikan selar dan ikan kembung dihistologi. Proses histologi diawali dengan pengeringan (dehidrasi), sampel retina dibungkus dengan kain kasa dan diikat dengan benang. Proses pengeringan dilakukan dengan merendam sampel retina ke dalam larutan alkohol dan xylene. Selanjutnya sampel retina ditanam pada blok parafin yang telah dipanaskan sebelumnya. Setelah blok parafin mengeras, dilakukan pemotongan spesimen retina dengan mikrotom. Hasil potongan spesimen retina ditempelkan pada gelas objek dan dilanjutkan pewarnaan spesimen. Spesimen yang telah diwarnai ditutup dengan kaca penutup. Spesimen retina ikan diamati di bawah mikroskop Olympus BX 41.

Lampu LED yang digunakan dalam penelitian adalah LED strip SMD 5050 IP 33 dengan warna putih, kuning, hijau dan biru. Jenis lampu ini memiliki cahaya yang terang dan hemat energi. Setiap mata lampu hanya membutuhkan daya sekitar 0,5 watt. 


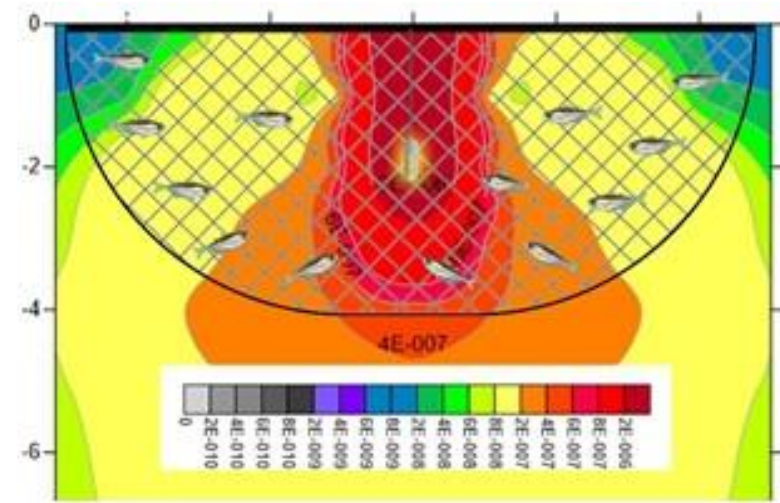

(a)

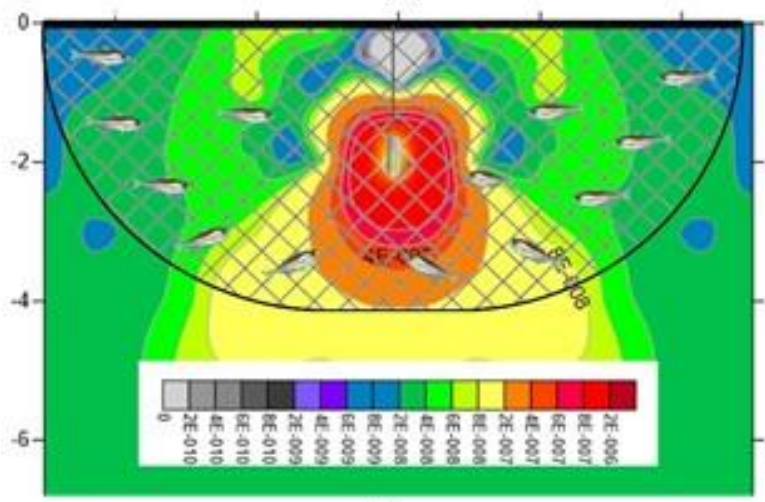

(c)



(b)

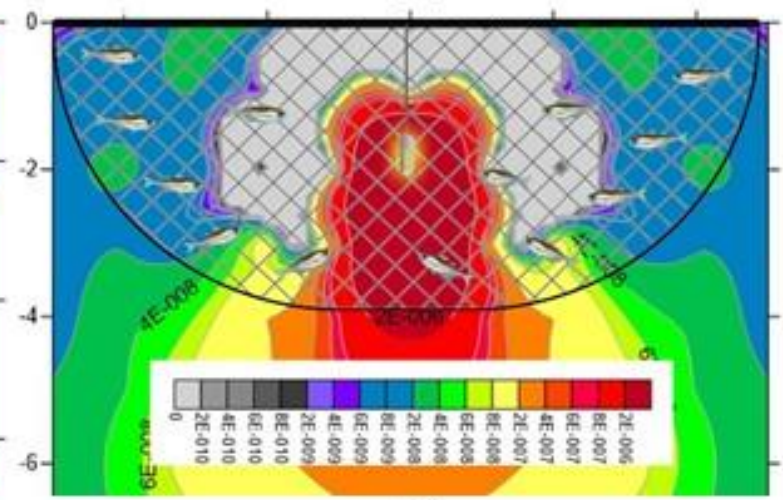

(d)

Figure 1. Number of treatments and the distribution of LED lights. (a) White LED (b) Yellow LED (c) Green LED (d) Blue LED.

Masing-masing warna lampu LED yang digunakan telah dilakukan pengukuran sebaran cahaya di air laut menggunakan international light technology (ILT) 5000. Hasil pengukuran sebaran cahaya ditumpang-tindih (overlay) dengan ukuran jaring pada bagan tancap. Hasil overlay menggambarkan sebaran dan jumlah energi cahaya yang diterima sampel ikan percobaan (Figure 1).

\subsection{Analisis Data}

Data hasil pengukuran panjang lintasan sel kon mata ikan ditabulasi dan dilakukan penghitungan indeks sel kon setiap sampel ikan. Data kecepatan pergerakan sel kon diuji korelasi dan regresi dengan ukuran panjang ikan untuk mengetahui hubungan dan pengaruh ukuran ikan. Penghitungan indeks sel kon mengacu pada Matsui et al. (2016) berikut ini:
$C=\frac{c^{t}}{A} x 100 \%$

Keterangan: $A=$ Jarak dari PEM ke OLM; $C^{\prime}=$ Jarak dari PEM ke bagian tengah sel kon (Figure 2).

Data panjang lintasan sel kon dan lama waktu pemberian cahaya lampu digunakan untuk mengetahui kecepatan pergerakan sel kon. Rumus kecepatan pergerakan sel kon mengacu pada rumus Matsui et al. (2016) sebagai berikut:

$V=\frac{\left(c^{t}-k\right)}{T}$

Keterangan: $C^{\prime}=$ Jarak dari PEM ke bagian tengah sel kon $(\mu \mathrm{m}) ; T=$ Lama waktu pemberian cahaya lampu LED (detik); $K=$ Rata-rata $C^{\prime}$ kontrol $(\mu \mathrm{m})$. 


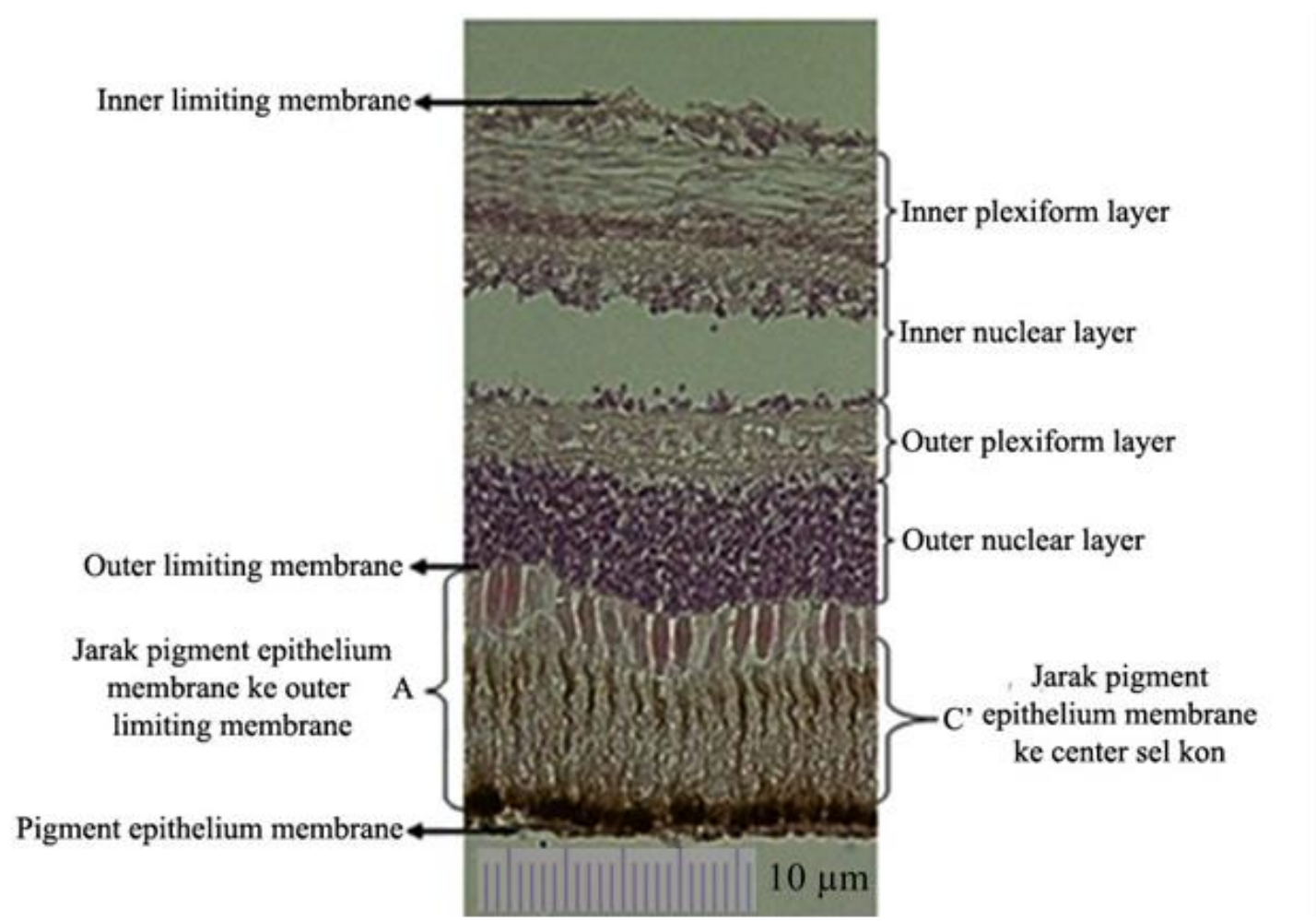

Figure 2. The part of retinal in the con index analysis.

\section{HASIL DAN PEMBAHASAN}

\subsection{Korelasi dan Regresi Ukuran Ikan}

Ikan yang berukuran kecil memiliki kecepatan pergerakan sel kon yang sama dengan ikan yang berukuran besar. Kecepatan pergerakan sel kon tidak memiliki korelasi dengan ukuran ikan. Berdasarkan hasil analisis menunjukkan bahwa tidak ada hubungan antara ukuran ikan selar dan ikan kembung dengan kecepatan pergerakan sel kon. Pengaruh ukuran ikan juga sangat kecil sekali terhadap kecepatan pergerakan sel kon. Hasil uji korelasi dan regresi di atas membuktikan bahwa kecepatan pergerakan sel kon ikan hanya dipengaruhi oleh jumlah energi cahaya yang diterima oleh mata ikan. Kecepatan pergerakan sel kon menunjukkan tingkat respons fisiologi ikan terhadap warna cahaya. Perbedaan respons ini dipengaruhi oleh kuantitas dan kualitas energi cahaya (Syam \& Satria, 2009; Siebeck et al., 2008). Pengaruh ukuran ikan selar terhadap kecepatan pergerakan sel kon hanya sebesar $5,4 \%$ (Figure 3a). Sedangkan pengaruh ukuran ikan kembung terhadap kecepatan pergerakan sel kon adalah 1,8\% (Figure $3 b$ ). Kecepatan pergerakan sel kon ikan selar cenderung menurun seiring meningkatnya panjang ikan. Kecepatan pergerakan sel kon ikan kembung semakin meningkat seiring dengan meningkatnya ukuran ikan.

\subsection{Indeks Sel Kon Ikan Selar dan Ikan Kembung}

Ikan selar sangat tertarik terhadap cahaya warna biru dan hijau. Ketertarikan ikan selar terhadap cahaya warna biru dan hijau ditunjukkan oleh panjang lintasan sel kon pada retina. Semakin panjang lintasan sel kon pada retina, maka semakin cepat pergerakan sel kon dari PEM ke OLM. Ratarata panjang lintasan sel kon ikan selar pada cahaya warna biru dan hijau adalah $32,37 \pm 5.03 \pi \mathrm{m}$ dan $27,69 \pm 3.2 \mu \mathrm{m}$. Rata-rata panjang lintasan sel kon ini dua kali lebih besar dibandingkan warna cahaya putih dan kuning. Perbandingan jarak antara PEM ke OLM dengan panjang lintasan sel kon dikenal dengan indeks sel kon. Indeks sel 


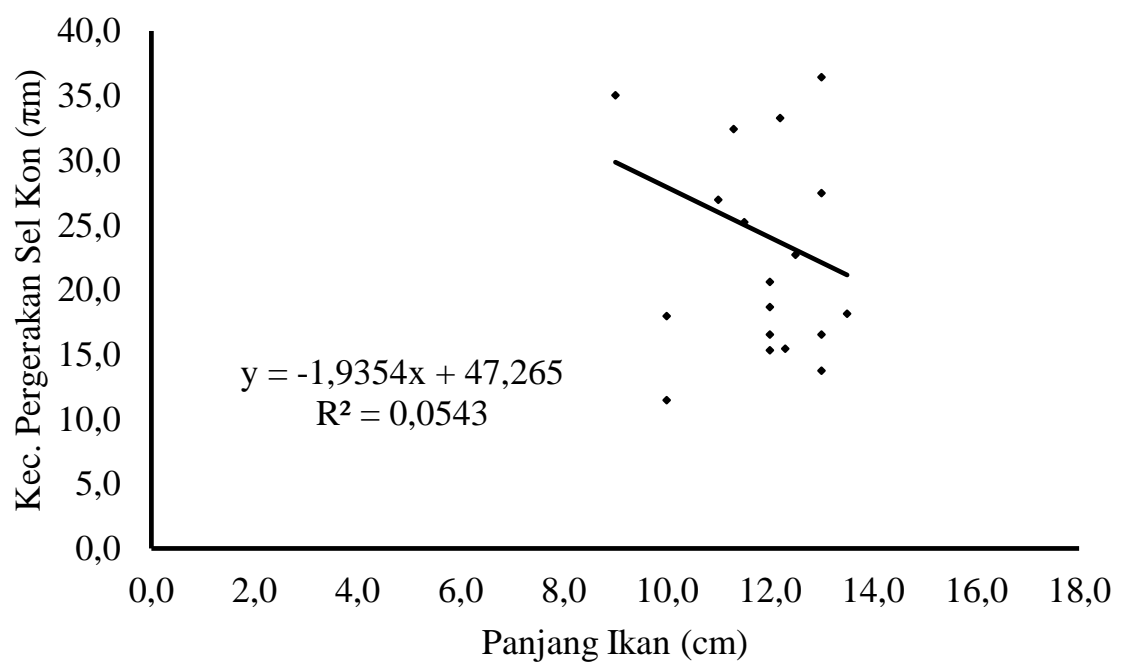

(a)

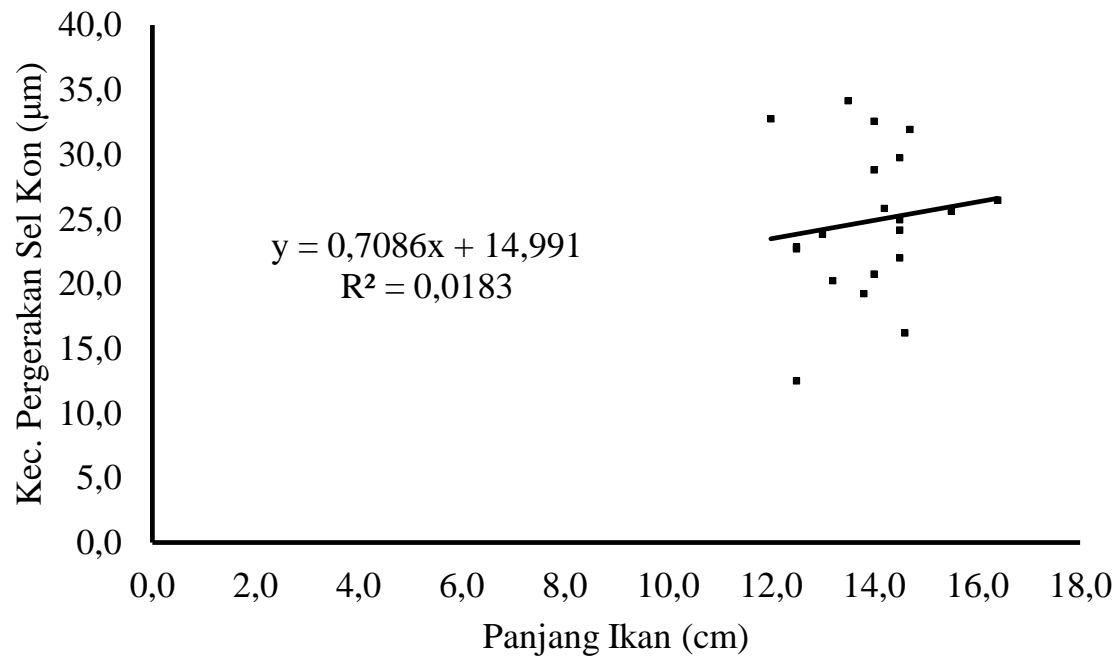

(b)

Figure 3. Relationship of fish length with the speed of the con cell movement (a) yellowstriped scad (b) short mackerel.

kon menjadi indikator untuk mengukur tingkat ketertarikan ikan terhadap warna cahaya. Semakin tinggi indeks sel kon, maka semakin tinggi tingkat ketertarikan ikan terhadap warna cahaya. Rata-rata indeks sel kon ikan selar pada cahaya warna biru dan hijau adalah $77,3 \pm 7,4 \%$ dan $70,7 \pm 6,8 \%$. Rata-rata indeks sel kon ini $25 \%$ lebih tinggi dibandingkan indeks sel kon pada warna cahaya putih dan kuning (Figure 4). Hal ini menunjukkan bahwa, cahaya warna biru dan hijau pada lampu LED mampu menarik ikan selar lebih cepat dibandingkan dengan cahaya warna putih dan kuning. Demikian sebaliknya, cahaya warna putih dan kuning lebih lambat menarik ikan selar. Panjang lintasan sel kon pada retina ikan selar lebih pendek. Rata-rata panjang lintasan sel kon ikan selar pada cahaya warna putih dan kuning adalah 19,25 $\pm 4,1 \pi \mathrm{m}$ dan 18,61 $\pm 1,9$ $\mu \mathrm{m}$. Sedangkan rata-rata indeks sel kon ikan selar pada cahaya warna putih dan kuning adalah $49,2 \pm 9,1 \%$ dan $48,3 \pm 5,5 \%$.

Panjang lintasan sel kon ikan kembung kontrol pada penelitian ini adalah $6,8 \pi \mathrm{m}-11,01 \mu \mathrm{m}$ dari PEM. Indeks sel kon ikan kembung kontrol adalah $23 \pm 1,7 \%$. Ikan kembung sangat tertarik terhadap cahaya 
warna biru. Rata-rata panjang lintasan sel kon ikan kembung adalah 25,7 $\pi \mathrm{m}$ dari PEM. Rata-rata indeks sel kon ikan kembung yang diberi cahaya warna biru adalah 79,9 2,0\% . Hal ini menunjukkan bahwa, cahaya lampu LED warna biru sangat cepat menarik ikan kembung, namun semakin cepat pula ikan kembung mencapai titik jenuh. Cahaya lampu LED warna hijau dan kuning cukup cepat menarik ikan kembung.

Rata-rata panjang lintasan sel kon ikan kembung pada cahaya warna hijau dan kuning adalah 28,28 $\pm 3,29 \mu \mathrm{m}$ dan $25,57 \pm 1,82 \pi \mathrm{m}$ dari PEM. Rata-rata indeks sel kon ikan kembung pada cahaya warna hijau dan kuning adalah $72,1 \pm 7,9 \%$ dan $71 \pm 6,0 \%$. Cahaya lampu LED warna hijau dan kuning lebih sesuai untuk menangkap ikan kembung. Respons ikan kembung cukup baik dan titik jenuh ikan lebih rendah dibandingkan cahaya biru. Respons ikan kembung terhadap cahaya warna putih cukup lambat. Hal ini ditunjukkan oleh pendeknya panjang lintasan sel kon pada retina ikan kembung. Rata-rata panjang lintasan sel kon ikan kembung pada cahaya warna putih adalah 19,85 $\pm 1,93 \mu \mathrm{m}$, sedangkan rata-rata indeks sel kon ikan kembung adalah $52,8 \pm 1,7 \%$.

\subsection{Kecepatan Pergerakan Sel Kon}

Kecepatan pergerakan sel kon merupakan salah satu indikator untuk menentukan tingkat ketertarikan ikan terhadap warna cahaya. Kecepatan pergerakan sel kon ikan selar yang diberi perlakuan cahaya warna biru memiliki kecepatan rata-rata $0,0180 \pm 0,0028 \mu \mathrm{m} /$ det. Sedangkan ikan kembung yang diberi perlakuan cahaya warna hijau memiliki kecepatan pergerakan sel kon rata-rata $0,0157 \pm 0,00183 \mu \mathrm{m} /$ det. Kecepatan pergerakan sel kon ini merupakan yang tertinggi diantara semua perlakuan warna cahaya. Kedua perlakuan warna cahaya di atas merupakan warna cahaya yang paling baik untuk mengumpulkan ikan selar dan ikan kembung dalam waktu singkat. Demikian sebaliknya, kecepatan pergerakan sel kon paling lambat terdapat pada ikan selar dan ikan kembung yang diberi cahaya warna kuning dan putih. Ikan selar dan ikan kembung yang diberi cahaya warna putih memiliki kecepatan pergerakan sel kon ratarata $0,0107 \pm 0,0023 \mu \mathrm{m} /$ det $\quad$ dan $0,010 \pm 0,00108 \mu \mathrm{m} /$ det. Ikan kembung yang diberi cahaya warna kuning memiliki kecepatan sel kon rata-rata $0,0103 \pm 0,00101$ $\mu \mathrm{m} /$ det (Figure 6).

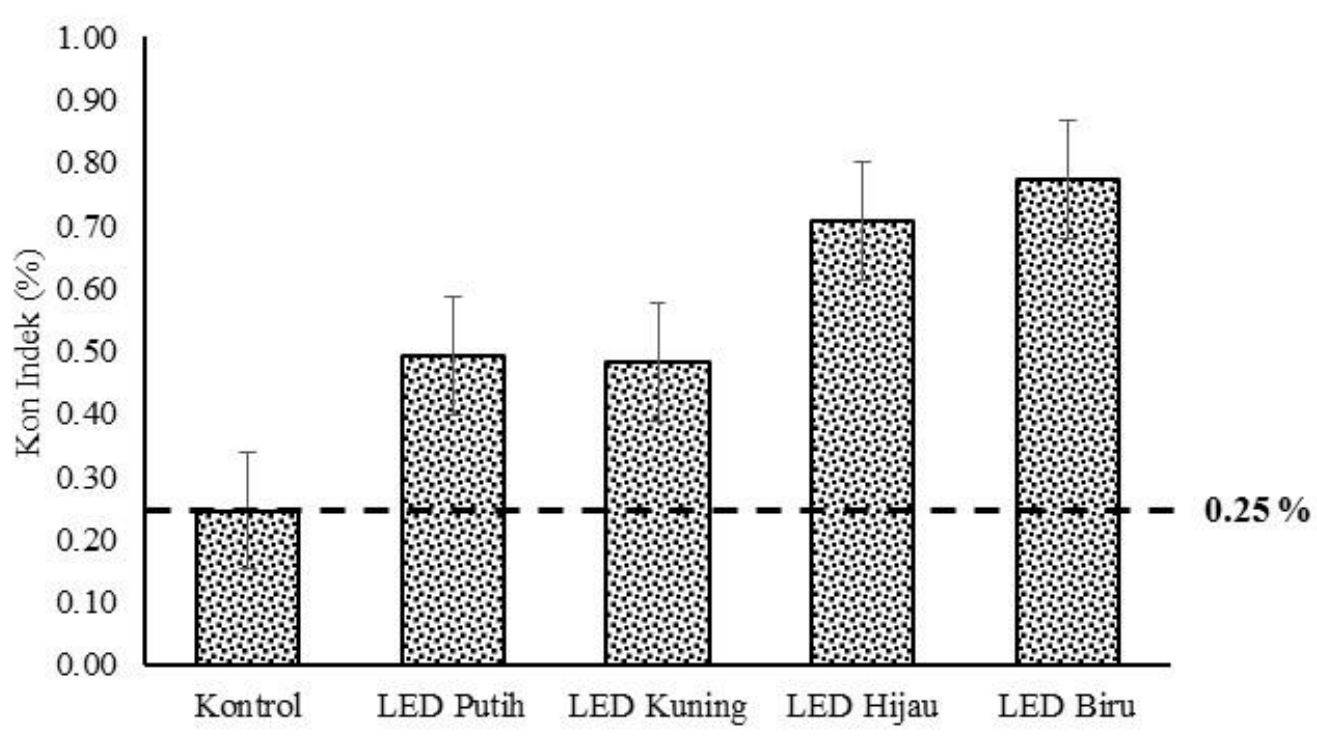

Figure 4. The con index of yellow-striped scad based on the color of LED lights. 


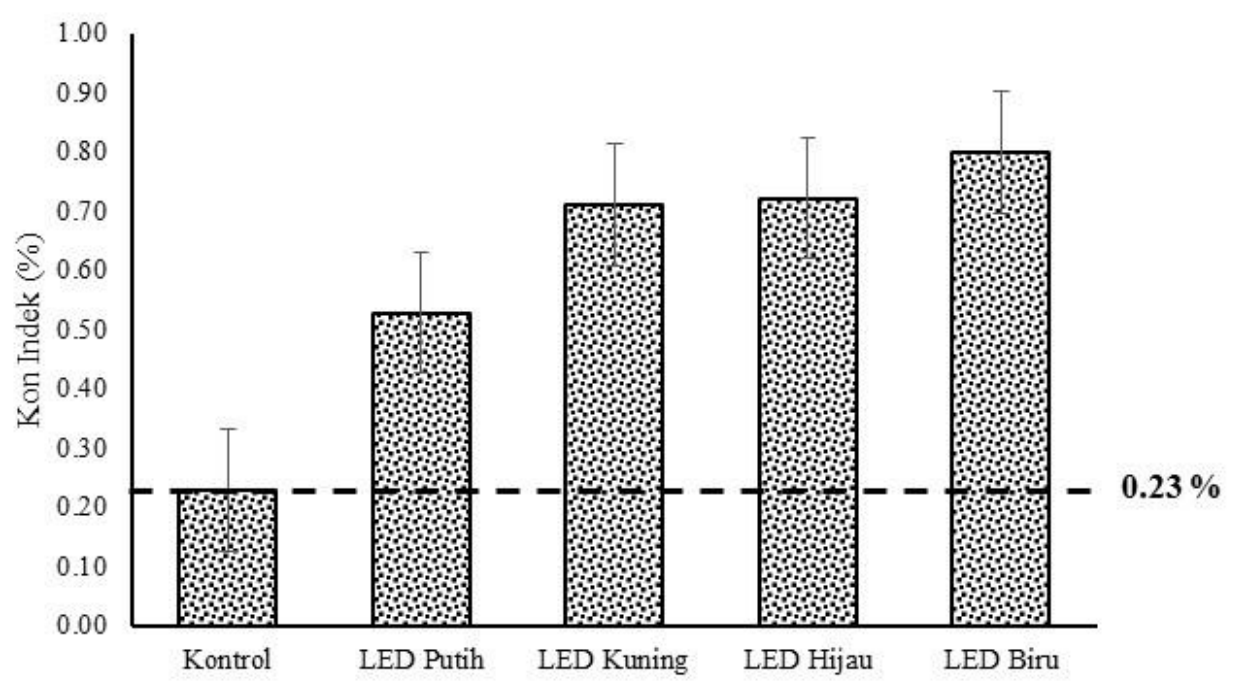

Figure 5. The con index of short mackerel based on the color of LED lights.

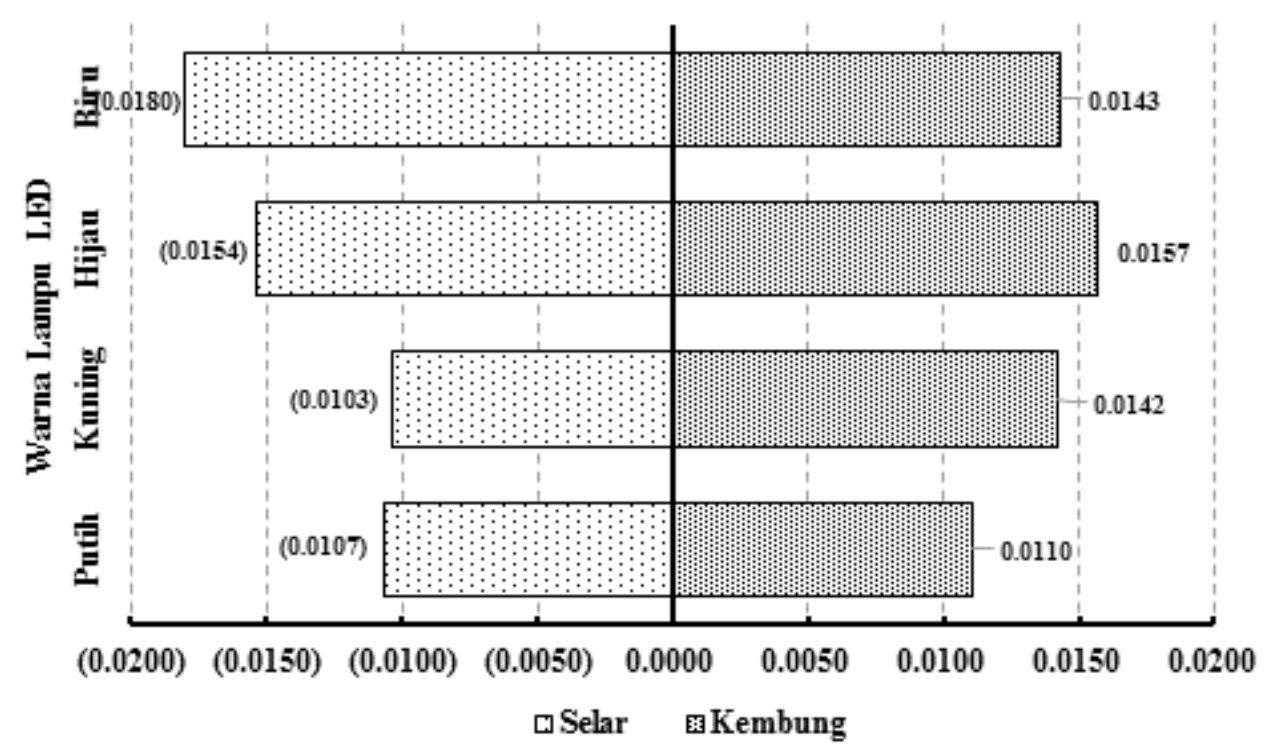

Figure 6. The speed of con cells movement to yellow-striped scad and short mackerel based on the color of the LED lights.

\subsection{Pembahasan}

Ikan selar dan ikan kembung yang terpapar cahaya akan menggerakkan sel konnya dari PEM ke OLM (Figure 7). Pergerakan sel kon ini dikenal dengan adaptasi penglihatan ikan. Satuan adaptasi penglihatan ikan yang dikenal saat ini adalah indeks sel kon. Indeks sel kon ikan berbeda untuk setiap jenis dan ukuran ikan. Indeks sel kon ikan juga dipengaruhi oleh panjang gelombang cahaya yang diberikan (Risner et $a l .$, 2006). Rata-rata indeks sel kon ikan selar kontrol pada penelitian ini adalah 0,25.
Panjang lintasan sel kon ikan selar kontrol adalah 5,8-10,9 $\mu \mathrm{m}$ dari PEM.

Pergerakan sel kon pada retina ikan bertujuan untuk mengontrol energi cahaya yang masuk ke dalam mata (Matsui et al., 2016). Mata ikan selar dan ikan kembung yang terpapar cahaya akan direspons oleh retina dengan menggerakkan sel kon dari PEM ke arah OLM. Sebaliknya, pada kondisi gelap, maka sel rod akan bergerak kearah OLM. Mekanisme ini disebut dengan retinomotor. Ikan selar dan ikan kembung memiliki sel kon yang terkonsentrasi pada 
daerah ventro temporal, hal ini menunjukkan bahwa ikan pelagis sangat menyukai kondisi lingkungan yang terang. Kecepatan respons ikan selar dan ikan kembung terhadap cahaya bisa diukur dari kecepatan pergerakan sel kon dari PEM ke OLM. Kecepatan respons ikan sangat dipengaruhi oleh warna dan intensitas cahaya yang diberikan. Cahaya warna biru yang digunakan untuk mengumpulkan ikan mendapatkan respons yang paling tinggi dibandingkan warna cahaya lainnya. Sedangkan cahaya warna putih dan kuning mendapatkan respons paling rendah.

Tingkat ketertarikan (respons) ikan selar dan ikan kembung terhadap cahaya juga bisa dilihat dari panjang lintasan sel kon pada retina mata ikan. Semakin panjang lintasan sel kon maka semakin tinggi ketertarikan (respons) ikan tersebut terhadap warna cahaya. Panjang lintasan sel kon diukur dari titik terluar PEM kebagian tengah sel kon. Sel kon yang telah mencapai lapisan OLM dikatakan mencapai titik jenuh (indeks sel kon mendekati 1) (Matsui et al., 2016). Ikan yang terpapar cahaya dan telah mencapai titik jenuh biasanya akan menjauhi sumber cahaya. Respons ini dilakukan untuk menjaga keseimbangan energi cahaya di dalam retina ikan. Setelah energi cahaya di dalam retina seimbang, ikan akan kembali mendekati sumber cahaya. Titik jenuh ikan sangat dipengaruhi oleh panjang lintasan dan kecepatan pergerakan sel kon. Semakin panjang lintasan sel kon maka semakin lama ikan mencapai titik jenuh. Semakin lambat kecepatan pergerakan sel kon, maka semakin lama ikan mencapai titik jenuh.

Setiap jenis ikan memiliki panjang lintasan dan kecepatan sel kon yang berbeda saat terpapar cahaya. Perbedaan inilah yang menyebabkan setiap jenis ikan memiliki titik jenuh yang berbeda pula. Rata-rata panjang lintasan sel kon ikan selar pada penelitian ini adalah 11,77 $\mu \mathrm{m}$, sedangkan ikan kembung 13,92 $\mu \mathrm{m}$. Kecepatan pergerakan sel kon ikan selar sekitar $0,0180 \pm 0,0028 \mu \mathrm{m} / \mathrm{det}$, sedangkan ikan kembung 0,0157 $\pm 0,00183$ $\mu \mathrm{m} /$ det. Strategi penangkapan ikan selar dan ikan kembung harus memperhatikan tingkat ketertarikan dan titik jenuh ikan. Tahap pencahayaan pada penangkapan ikan selar dan ikan kembung sebaiknya tidak melebihi 45 menit.

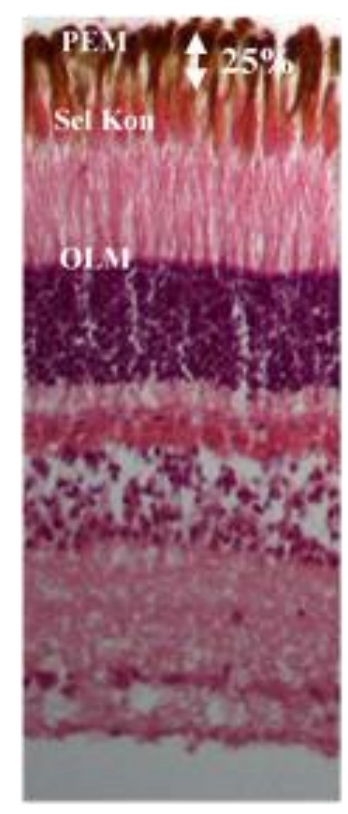

a

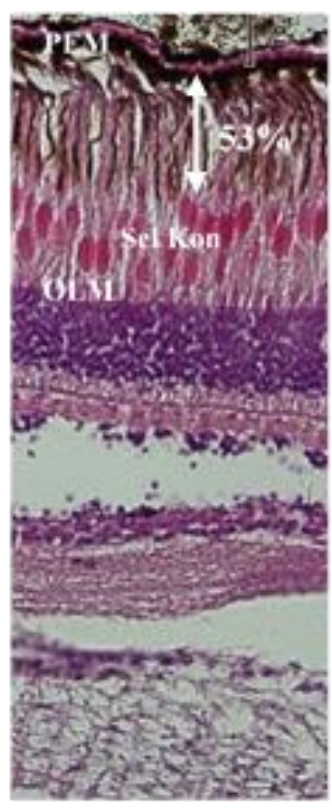

$\mathrm{b}$

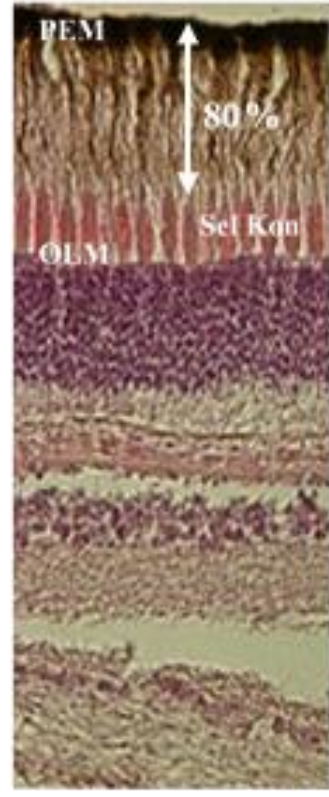

c

Figure 7. Retinal response of fish eye based on conditions (a) Dark adaptation (25\%) (b) Transition (53\%) (c) Bright adaptation (80\%). 
Ikan memiliki dua jenis sel pada retina untuk merespons keberadaan cahaya (Kelber, 2016). Sel kon berfungsi untuk merespons kondisi terang dan sel rod untuk merespons kondisi gelap. Ikan yang memikili jumlah sel kon dominan (bikromatik), biasanya lebih menyukai perairan yang terang. Jenis ikan ini berenang dan mencari makan dipermukaan perairan. Ikan-ikan pelagis (bikromatik) akan mendekati cahaya lampu pada saat malam hari. Indra penglihatan ikan bikromatik memiliki sensitifitas yang tinggi terhadap cahaya. Disisi lain, ikan yang hanya memiliki sel rod (monokromatik) lebih tertarik pada perairan yang gelap. Ikan monokromatik memiliki visual pigmen tunggal, sehingga sangat sulit membedakan warna di lingkungan sekitarnya. Kelompok ikan monokromatik banyak didominasi oleh ikan-ikan dasar yang sulit mendapatkan cahaya. Menurut Marshall et al. (2015), ikan dibagi mejadi dua kelompok berdasarkan tingkat sensitifitas terhadap cahaya yaitu monokromatik dan bikromatik. Ikan selar dan ikan kembung termasuk dalam kelompok ikan bikromatik yang memiliki sensitifitas tinggi terhadap cahaya. Ikan selar dan ikan kembung juga mampu mem-bedakan warna cahaya dengan jelas. Kedua jenis ikan ini mampu merespons dengan cepat cahaya warna hijau dan biru.

Berdasarkan sifat-sifat fisiologi ikan, nelayan membuat suatu teknologi untuk mempermudah proses penangkapan ikan. Nelayan membuat lampu pemikat ikan sebagai alat bantu penangkapan. Lampu pemikat ikan berfungsi untuk menarik ikan agar berkumpul pada satu titik sebelum dilakukan penangkapan. Hasil kajian fisiologi ikan juga digunakan sebagai stimulan untuk mempercepat pertumbuhan ikan tertentu. Efek warna cahaya digunakan untuk meningkatkan hormon pertumbuhan pada ikan. Meningkatnya hormon pertumbuhan ikan erat kaitannya dengan jumlah energi dan panjang gelombang cahaya yang masuk melalui pupil dan retina mata ikan. Jenis ikan yang bisa beri stimulan cahaya untuk pertumbuhan adalah ikan-ikan yang visual pigmen ganda seperti ikan cod, mackerel dan herring. Pertumbuhan ikan cod lebih cepat jika diberi stimulan cahaya warna hijau dan biru (Utne-Palm et al., 2018; Villamizar et al., 2011; Sierra-Flores et al., 2016). Cahaya lampu warna hijau dan biru juga sangat disukai oleh ikan mackerel (Matsushita et al., 2012; Choi et al., 2009). Beberapa penelitian di atas sejalan dengan hasil penelitian ini, yang mana ikan-ikan bikromatik (visual pigmen ganda) sangat menyukai warna cahaya yang memiliki panjang gelombang antara $450 \mathrm{~nm}$ sampai $550 \mathrm{~nm}$.

\section{KESIMPULAN}

Ikan selar (S. leptolepis) sangat tertarik terhadap cahaya lampu LED warna hijau $(550 \mathrm{~lm} / \mathrm{m})$ dan biru $(170 \mathrm{~lm} / \mathrm{m})$, sedangkan ikan kembung ( $R$. brachysoma) sangat tertarik terhadap cahaya lampu LED warna biru $(170 \mathrm{~lm} / \mathrm{m})$. Ikan selar dan ikan kembung kurang tertarik terhadap cahaya lampu LED warna puth dan kuning. Semakin tinggi tingkat ketertarikan ikan selar dan ikan kembung terhadap warna cahaya maka semakin cepat pula ikan tersebut mencapai titik jenuh.

\section{UCAPAN TERIMAKASIH}

Terima kasih disampaikan kepada seluruh dosen Jurusan Teknologi Perikanan Laut FPIK-IPB, Kementerian Riset, Teknologi dan Pendidikan Tinggi dan LPDP yang telah membiayai penelitian ini. Terimakasih juga disampaikan kepada teman-teman nelayan, Bapak Fathul, Saad, Nur Habibi, Syafik dan Supriyadi yang telah membantu kami selama pelaksanaan penelitian di perairan Selat Madura. Terima kasih juga kepada teman-teman di Program Doktor Teknologi Perikanan Laut FPIK IPB yang telah memberikan motivasi selama penelitian. 


\section{DAFTAR PUSTAKA}

Choi J.S., S.K. Choi, S.J. Kim, G.S. Kil, \& C.Y. Choi. 2009. Photoreaction analysis of squids for the development of a LED-fishing lamp in: Lupulescu, NB., N.E. Mastorakis, D. Lepadatescu. Proceedings of the 2nd International Conference on Maritime and Naval Science and Engineering. Transilvania University of Brasov, WSEAS Press. Rumania. 92-95 pp. http://www.wseas.us/elibrary/conferences/2009/brasov/MN/ MN16.pdf

Fuad, M.S. Baskoro, M. Riyanto, \& W. Mawardi. 2019. Catch characteristics on stationary lift net using light emitting diode (LED) and kerosene lights in Pasuruan waters. $J$. $A A C L$ Bioflux, 12(2): 490-501. http://www.bioflux.com.ro/docs/2019 .490-501.pdf

Guntur, Fuad, \& A. Muntaha. 2015. Effect of underwater lamp intensity on the lift nets fishing catches. J. Marine Fisheries, 6(2): 195-202. https://doi.org/10.29244/jmf.6.2.195202

Jeong H., S. Yoo, J. Lee, \& Y-II An. 2013. The retinular responses of common squid Todarodes pasificus for energy efficient fishing lamp using LED. Renewable Energy, 54: 101-104. http://doi.org/10.1016/j.renene.2012.0 8.051

Kelber, A. 2016. Colour in the eye of the beholder: receptor sensitivities and neural circuits underlying colour opponency and colour perception. Current Opinion in Neurobiology, 41: 106-112. http://doi.org/10.1016/j.conb.2016.09. 007

Kurnia, M., Sudirman, \& A. Nelwan. 2015. Studi pola kedatangan ikan pada area penangkapan bagan perahu dengan teknologi hidroakustik. J. IPTEKS PSP, 2(3): 261-271. http://doi.org/10.20956/jipsp.v2i3.79

Marchesan, M., M. Spoto, L. Verginella, \& E.A. Ferrero. 2005. Behavioral effects of artificial light on fish species of commercial interest. Fisheries Research, 73: 171-185. https://doi.org/10.1016/j.fishres.2004. 12.009

Marshall, J., K.L. Carleton, \& T. Cronin. 2015. Colour vision in marine organisms. Current Opinion in Neurobiology, 34: 86-94. https://doi.org/10.1016/j.conb.2015.0 2.002

Matsui, H., G. Takayama, \& Y. Sakurai. 2016. Physiological response of the eye to different colored light emitting diodes in Japanese flying squid Todarodes pacificus. Fisheries Science, 82(1): 303-309. https://doi.org/10.1007/s12562-0150965-5

Matsushita, Y., T. Azuno, \& Y. Yamashita. 2012. Fuel reduction in coastal squid jigging boats equipped with various combinations of conventional metal halide lamps and low-energy LED panels. Fisheries Research, 125-126: 14-19.

https://doi.org/10.1016/j.fishres.2012. 02.004

Nguyen, K.Q. \& P.D. Winger. 2019. Artificial light in commercial industrialized fishing applications. A review in fisheries science and aquaculture, 27(1): 106-126. https://doi.org/10.1080/23308249.201 8.1496065

Pankhurst, N.W. \& N.A. Herbert. 2013. Fish physiology and ecology: the contribution of the Leigh Laboratory to the collision of paradigms. New Zealand J. of Marine and Freshwater Research, 47(3): 392-408. https://doi.org/10.1080/00288330.201 3.808236 
Risner, M.L., E. Lemerice, E.V. Vulmanic, \& A. Moore. 2006. Behavioral spectral sensitivity of the zebrafish (Danio rerio). Vision Research, 46: 26252635.

https://doi.org/10.1016/j.visres.2005.1 2.014

Riyanto, M., A. Purbayanto, \& D.S.S. Natsir. 2011. Analisis indra penglihatan ikan kerapu macan (epinephelus fuscoguttatus) dan hubungannya dalam merespons umpan. J. Marine Fisheries, 2(1): 29-38. https://doi.org/10.29244/jmf.2.1.2938

Shen, S.C., C.Y. Kuo, \& M.C. Fang. 2013. Design and analysis of an underwater white LED fish-attracting lamp and its light propagation. International $J$. of Advanced Robotic Systems, 10: 110. https://doi.org/10.5772/56126

Siebeck, U.E., G.M. Wallis, \& L. Litherland. 2008. Colour vision in coral reef fish. J. of Experimental Biology, 211: 354360. https://doi.org/10.1242/jeb.012880

Sierra-Flores, R., A. Davie, B. Grant, S. Carboni, T. Atack, \& H. Migaud. 2016. Effects of light spectrum and tank background colour on Atlantic cod (Gadus morhua) and turbot (Scophthalmus maximus) larvae performances. Aquaculture. 450: 613.

https://doi.org/10.1016/j.aquaculture. 2015.06.041

Susanto, A., R. Irnawati, Mustahal, \& M.A. Syabana. 2017. Fishing efficiency of
LED lamp for fixed lift net fisheries in Banten bay Indonesia. Turkis J. of Fisheries and Aquatic Science, 17: 283-291.

https://doi.org/10.4194/1303-2712v17_2_07

Syam, A.R. \& H. Satria. 2009. Adaptasi fisiologis retina mata dan tingkah laku ikan terhadap cahaya. J. BAWAL, 2(5): 215-224.

https://doi.org/10.15578/bawal.2.5.20 09.215-224

Utne-Palm, A.C., M. Breen, S. Løkkeborg, \& O.B. Humborstad. 2018. Behavioral responses of krill and cod to artificial light in laboratory experiments. PLoS ONE, 13(1): e0190918.

https://doi.org/10.1371/journal.pone.0 190918

Villamizar, N., B. Blanco-Vives, H. Migaud, A. Davie, S. Carboni, \& F.J. SanchezVazquez. 2011. Effects of light during early larval development of some aquacultured teleosts: A review Aquaculture, 315: 86-94. https://doi.org/10.1016/j.aquaculture. 2010.10.03

Yeh, N., T.J. Ding, \& P. Yeh. 2015. Light emitting diodes qualities and their corresponding scientific applications. Renewable and Sustainable Energy Reviews, 52: 55-61. http://doi.org/10.1016/j.rser.2015.04.1 77

Received : 17 July 2019

Reviewed : 16 March 2020

Accepted : 10 April 2020 